\title{
1-Methylcyclopropene delays tomato fruit ripening
}

\author{
Celso Luiz Moretti'; Alessandra L. Araújo; Waldir Aparecido Marouelli; Washington Luiz C. Silva
}

${ }^{1}$ Bolsista CNPq; Embrapa Hortaliças, C. Postal 218, 70.359-970 Brasília-DF;E-mail: celso@cnph.embrapa.br

\begin{abstract}
Tomato (Lycopersicon esculentum Mill.) fruits, cv. Santa Clara, were harvested at the breaker stage from commercial fields in Brazlândia, Brazil, to investigate the ability of 1-methylcyclopropene (1-MCP) to retard tomato fruit ripening. Fruit without external blemishes were graded for size (diameter $=80 \pm 5 \mathrm{~mm})$ and mass $(\mathrm{m}$ $=130 \pm 10 \mathrm{~g}$ ), placed inside hermetically sealed boxes, and 1-MCP was applied for 12 hours $\left(\mathrm{T}=22 \pm 1^{\circ} \mathrm{C} ; \mathrm{RH}=80-85 \%\right)$ at four different concentrations: 0 (control), 250, 500 and $1000 \mathrm{~mL} . \mathrm{L}^{-1}$. Fruits were held at ambient conditions ( $\mathrm{T}=23 \pm 2^{\circ} \mathrm{C}$; $\left.\mathrm{RH} 80-85 \%\right)$ for 2 days and then stored inside a cold room $\left(\mathrm{T}=20 \pm 1{ }^{\circ} \mathrm{C}\right.$; $\left.\mathrm{RH}=85-95 \%\right)$. Every 3 days, during a 15-day period, fruits were analyzed for firmness, total soluble solids, titratable acidity, external color, and total carotenoids. Firmness of fruit treated with $1000 \mathrm{~mL} . \mathrm{L}^{-1}$ was about $88 \%$ higher than control fruits after 17 days. The $\mathrm{a}^{*} / \mathrm{b}^{*}$ ratio, an indicator of skin color, for fruit treated with $1000 \mathrm{~mL}^{-\mathrm{L}^{-1}}$ of 1MCP was $38 \%$ lower than control fruits at the end of the storage period. Treatments with higher concentrations of 1-MCP delayed total carotenoids synthesis and color development. Control fruits stored for 17 days had about $190 \%$ more total carotenoids than fruits treated with $1000 \mathrm{~mL} . \mathrm{L}^{-1}$ of 1-MCP. Postharvest application of 1MCP was an efficient method to delay tomato fruit ripening. As 1MCP concentration increased, ripening was further delayed. Tomatoes treated with 250,500 , and $1000 \mathrm{~mL} . \mathrm{L}^{-1}$ of $1-\mathrm{MCP}$ were delayed by 8 to 11,11 to 13 and 15 to 17 days, respectively.
\end{abstract}

Keywords: Lycopersicon esculentum, acidity, color, carotenoids, ethylene, firmness, postharvest.

\section{RESUMO}

Retardamento do amadurecimento de tomates com 1metilciclopropeno

Tomates (Lycopersicon esculentum Mill.), 'Santa Clara', foram colhidos no estádio verde-rosado em campos de produção comercial em Brazlândia (DF) com o objetivo de investigar a capacidade do 1-metilciclopropeno (1-MCP) em retardar o amadurecimento de tomates. Frutos sem danos mecânicos externos aparentes foram selecionados para tamanho (diâmetro $=80 \pm 5 \mathrm{~mm})$ e massa $(\mathrm{m}=130 \pm 10$ $\mathrm{g}$ ), foram colocados em câmaras herméticas, e 1-MCP foi aplicado por um período de 12 horas $\left(\mathrm{T}=22 \pm 1^{\circ} \mathrm{C} ; \mathrm{RH}=80-85 \%\right)$, em quatro concentrações diferentes: 0 (controle), 250, 500 e 1000 mL.L - $^{-1}$. Os frutos foram mantidos por dois dias em condições ambiente $(\mathrm{T}=$ $23 \pm 2^{\circ} \mathrm{C}$; RH $80-85 \%$ ) e posteriormente armazenados em câmara fria $\left(\mathrm{T}=20 \pm 1{ }^{\circ} \mathrm{C} ; \mathrm{RH}=85-95 \%\right)$. A cada 3 dias, durante um período de 15 dias, os frutos foram analisados para firmeza, sólidos solúveis totais, acidez total titulável, coloração externa e teor de carotenóides totais. Frutos tratados com $1000 \mathrm{~mL} . \mathrm{L}^{-1}$ possuíam firmeza $88 \%$ maior do que frutos do tratamento controle após dezessete dias de armazenamento. A relação a*/b*, um indicativo da coloração da casca, foi $38 \%$ menor em tomates tratados com 1000 mL.L $\mathrm{L}^{-1}$ quando comparados com frutos do tratamento controle ao final do experimento. Frutos tratados com as maiores dosagens de 1-MCP apresentaram o maior retardamento da síntese e revelação dos pigmentos carotenóides. Tomates provenientes do tratamento controle possuíam ao redor de $190 \%$ mais pigmentos carotenóides do que frutos tratados com $1000 \mathrm{~mL} . \mathrm{L}^{-1}$ de $1-\mathrm{MCP}$ ao final do experimento. A aplicação pós-colheita de 1-MCP foi um método eficiente em retardar o amadurecimento de tomates. À medida que aumentou-se a concentração do produto, observou-se um maior retardamento do amadurecimento. Tomates tratados com 250, 500, e 1000 mL.L ${ }^{-1}$ de 1-MCP tiveram o amadurecimento retardado em 8 a 11,11 a 13 e 15 a 17 dias, respectivamente.

Palavras-chave: Lycopersicon esculentum, acidez, coloração, carotenóides, etileno, firmeza, pós-colheita.

\section{(Recebido para publicação em 21 de dezembro de 2001 e aceito em 08 de abril de 2002)}

E thylene plays a key role in the ripening of climateric fruits such as tomatoes by triggering several ripeningrelated physiological changes (Lelièvre $e t$ al., 1997). Many compounds have shown the ability to block the ethylene binding site, causing either the supression or the inhibition of ethylene effects (Sisler et al., 1990; Sisler, 1991). Diazocyclopentadiene and 2,5 norbonadiene have shown the ability to control both ripening and softening of apples (Blankenship \& Sisler, 1993). However, none of these compounds is commercially acceptable due to toxicity and manufacturing concerns (Fan et al., 1999).

Other compounds with potential use are aminooxyacetic acid (AOA), aminoethoxyvinylglycine (AVG), and silver thiosulfate (STS). The effectiveness of AOA and AVG are reduced if external sources of ethylene are available, such as climateric fruits, fungi, propane, and cigarette smokes (Abeles et al., 1992). Amongst the inhibitors mentioned above, only STS has commercial applications in many countries. However, its continued use is being questioned as silver is a potent pollutant, and many countries have proposed to prohibit its use (Abdi et al., 1998).

Recently, a novel gaseous compound, 1-methylcyclopropene (1$\mathrm{MCP}$ ), has been reported to have inhibitory effects on ethylene action in various cut flowers and potted plants (Serek et al., 1994; 1995), plums (Abdi et al., 1998), apples (Fan et al., 1999), 
bananas (Golding et al., 1998; Jiang et al., 1999), citrus (Porat et al., 1999), strawberries (Ku et al., 1999), broccoli (Ku and Wills, 1999), and lettuce (Fan and Mattheis, 2000).

Tomato fruit handling, transportation, ripening and marketing involves sophisticated technology and facilities. A non-sophisticated technology to extend tomatoes shelf life at ambient conditions and with minimal impacts to the environment is needed to increase the competitiveness of this commodity in different countries.

The objective of the present work was to investigate the ability of 1-MCP to retard tomato fruit ripening.

\section{MATERIAL AND METHODS}

\section{Plant material}

Tomato (Lycopersicon esculentum Mill.) fruits 'Santa Clara', were harvested at the breaker stage (USDA, 1985) from commercial fields in Brazlândia, Brazil. After harvest, fruits with external blemishes were removed and the remaining fruits were graded for size $($ diameter $=80 \pm 5 \mathrm{~mm}$ ) and mass $(130 \pm 10 \mathrm{~g})$ and placed inside hermetically sealed boxes (volume $=80$ L) for 1-MCP treatment. Each box contained $55 \pm 0.3 \mathrm{~kg}$ of tomatoes. Mini- fans were placed inside the boxes, attached to the lids, in order to make sure that 1-MCP dispersion would be as efficient as possible.

\section{1-MCP preparation}

Ethylbloc $^{\circledR}(0.14 \%$ active ingredient $)$ was used to release 1 -MCP. It is formulated into a powder that releases 1-MCP when mixed in a diluted base or water. Mixing was carried out inside sealed glass jars placed in the center of the application boxes, where the required concentrations of $1-\mathrm{MCP}$ were obtained by adding heated $\left(40-60^{\circ} \mathrm{C}\right)$ sodium lauril sulphate solution (1000 mg. $\left.\mathrm{kg}^{-1}\right)$ to appropriate amounts of the 1-MCP powder. Glass jars were opened, and 1-MCP was released in the vapor phase at the following concentrations: 0, 250, 500 and $1000 \mathrm{~mL} \cdot \mathrm{L}^{-1}$.

\section{Fruit treatment}

Fruits were treated with 1-MCP in the concentrations mentioned above for 12 hours at $22 \pm 1^{\circ} \mathrm{C}$ and 80 to $85 \% \mathrm{RH}$. After treatment, fruits were left at ambient conditions $\left(23 \pm 1^{\circ} \mathrm{C}\right.$; RH 80 $85 \%$ ) for 2 days to simulate handling conditions encountered in commercial marketing in Brazil. After this 2-day period, fruits were stored at $20 \pm 1^{\circ} \mathrm{C}$ and $85-95 \%$ RH for 15 days to simulate the best ripening conditions, and every 3 days were analyzed for firmness, total

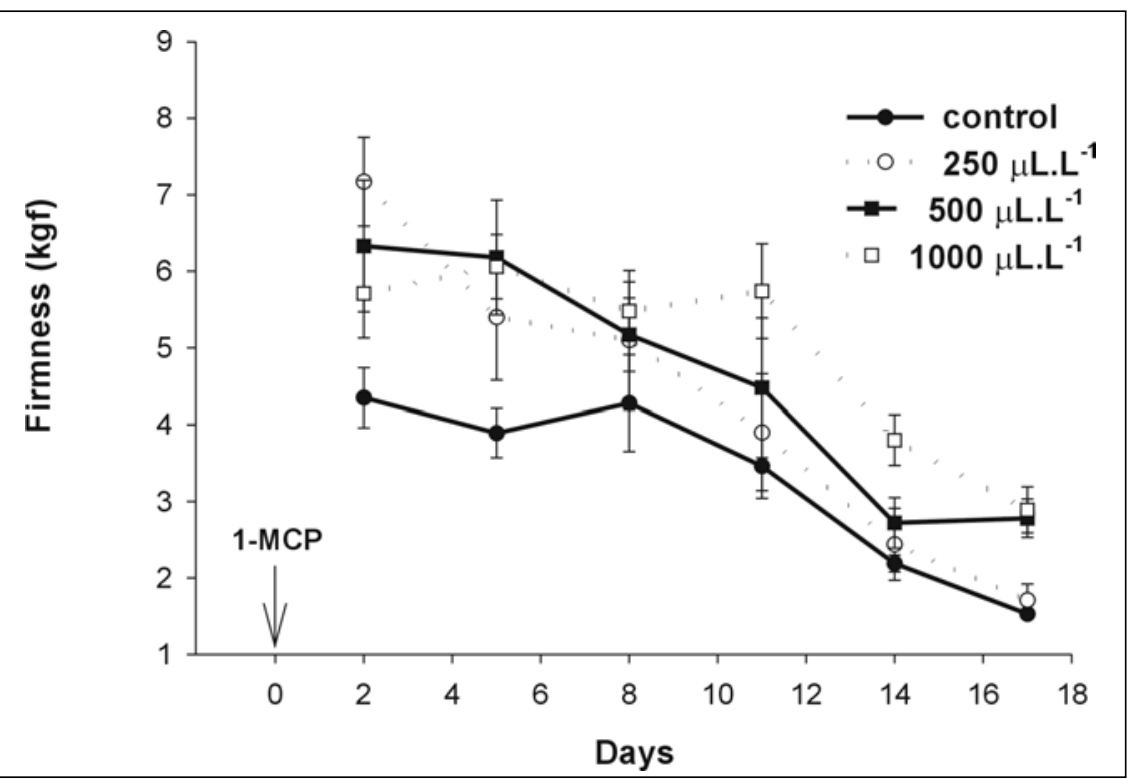

Figure 1. Firmness (kgf) of tomato fruits treated with 1-MCP, stored for 2 days at ambient conditions $\left(23 \pm 1^{\circ} \mathrm{C}\right.$; $\left.\mathrm{RH} 80-85 \%\right)$ with subsequent storage for 15 days at $20 \pm 1^{\circ} \mathrm{C}$ and $85-$ $95 \%$ RH. Vertical bars indicate \pm SD. soluble solids, titratable acidity, color, and total carotenoids.

\section{Firmness}

Firmness was assayed using a hand penetrometer ( $8 \mathrm{~mm}$ probe). Three fruits, in each replication, were penetrated at opposite sides of their equatorial axes.

Titratable acidity and soluble solids

For the determination of titratable acidity and soluble solids content, $40 \mathrm{~g}$ of fresh tissue were homogenized in a commercial blender at high speed and centrifuged for $15 \mathrm{~min}$ at $18,000 \mathrm{~g}$. Aliquots of the supernatant were diluted with $50 \mathrm{~mL}$ of deionized water and titrated with $0.1 \mathrm{~N} \mathrm{NaOH}$ to an end point of $\mathrm{pH} 8.2$ using an automatic titrimeter. The amount of $\mathrm{NaOH}$ was converted to miliequivalents of citric acid per $\mathrm{kg}$ of fresh weight $(\mathrm{mL} \mathrm{NaOH} \times 0.1 \mathrm{~N}$ x $0.064)$. Soluble solids content was determined using a benchtop digital refractometer.

\section{Color}

For color assessment, fruits were marked along their equatorial axes and three readings were taken using a Minolta Chromo Meter, model CR 200b. Color was expressed as the ratio between $a^{*}$ and $b^{*}$ parameters. Ratios $a^{*} / b^{*}>0$ indicate that the predominant color of the fruit surface is that of a mature fruit (red, in the case of tomatoes). On the other hand, a ratio $\mathrm{a}^{*} /$ $b^{*}<0$ indicates color of immature fruit (green, for tomatoes).

\section{Total carotenoids}

Total carotenoids were analyzed according to Lime et al. (1957) and Umiel \& Gabelman (1971), modified by Moretti et al. (1998). Pigment was extracted by homogenizing $15 \mathrm{~g}$ of fresh tissue with $30 \mathrm{~mL}$ of acetone in a Polytron (PT 1200, Brinkmann Instruments, Westbury, NY) for $1 \mathrm{~min}$ at a speed setting of 5 . The acetonepigment extract and $45 \mathrm{~mL}$ of hexane were mixed in a separatory funnel and, after phase separation, the lower phase was discarded and the pigment-hexane extract was washed three times with 100 $\mathrm{mL}$ of deionized water. After the final wash, the extract was transferred to a 100-mL volumetric flask and the volume was brought up with hexane. 
Absorbance was read in a spectrophotometer (Hitachi Model 550, Japan) at $451 \mathrm{~nm}$ and $503 \mathrm{~nm}$. Total carotenoids were expressed as mg per $\mathrm{kg}$ of fresh tissue.

\section{Statistical analysis}

Analyses were performed using a completely randomized design, with 24 treatments arranged in a factorial scheme (four 1-MCP concentrations and six sampling times), and 4 replicates $(n=8)$. Data were subjected to analysis of variance and the least significant difference procedure was carried out. Differences between any two treatments larger than the sum of two standard deviations were always significant $(\mathrm{P}=0.05)$.

\section{RESULTS AND DISCUSSION}

\section{Firmness}

Fruits treated with higher concentrations of 1-MCP were firmer than control fruits during the entire experiment. Two days after application, fruits treated with $1000 \mathrm{~mL} . \mathrm{L}^{-1}$ of 1MCP were around $50 \%$ firmer than control fruit. As fruits ripened, firmness of treated and control fruits decreased gradually (Figure 1). Firmness of control fruits and fruits treated with $250 \mathrm{~mL} . \mathrm{L}^{-}$ ${ }^{1}$ of 1-MCP were similar at the end of the storage period, whereas fruits treated with $1000 \mathrm{~mL} . \mathrm{L}^{-1}$ were significantly firmer than control fruits (Figure 1).

Our results are supported by the findings of Jiang et al. (1999) and Fan et al. (1999), who observed that 1-MCP application retarded softening of banana fruits and "Ginger Gold" apples, respectively. On the other hand, Porat et al. (1999) observed that 1-MCP had no effect on citrus fruits firmness.

\section{Total soluble solids}

Control and 1-MCP treated fruits had similar total soluble solids content during the entire experiment. Between 8 and 11 days after 1-MCP application, control fruits had a significant increase in total soluble solids content ( $>$ than $4.0^{\circ}$ Brix ), whereas fruits treated with 1-MCP had an average total soluble solids content of 3.80 (Figure 2). By the end of the storage period, there were no significant differences in soluble solids for all treatments (Figure 2).

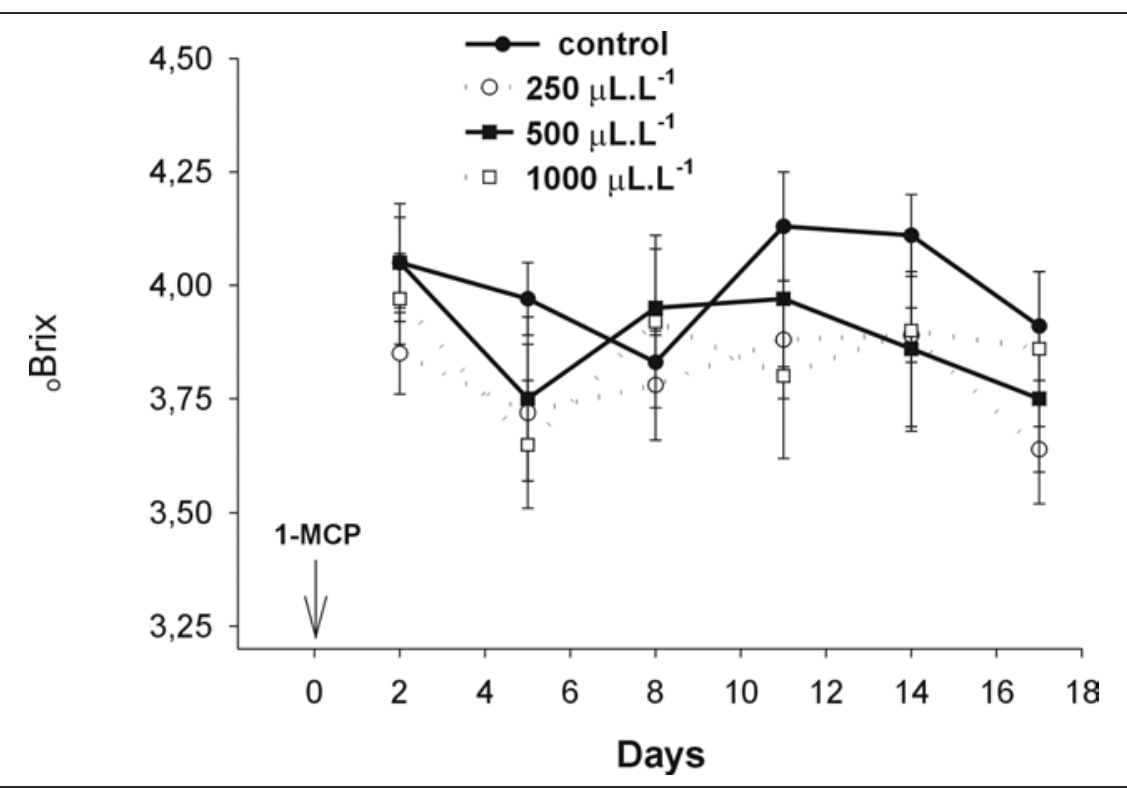

Figure 2. Total soluble solids ( ${ }^{\circ}$ brix) of tomato fruits treated with 1-MCP, stored for 2 days at ambient conditions $\left(23 \pm 1^{\circ} \mathrm{C}\right.$; RH $\left.80-85 \%\right)$, with subsequent storage for 15 days at $20 \pm 1{ }^{\circ} \mathrm{C}$ and $85-95 \%$ RH. Vertical bars indicate \pm SD.

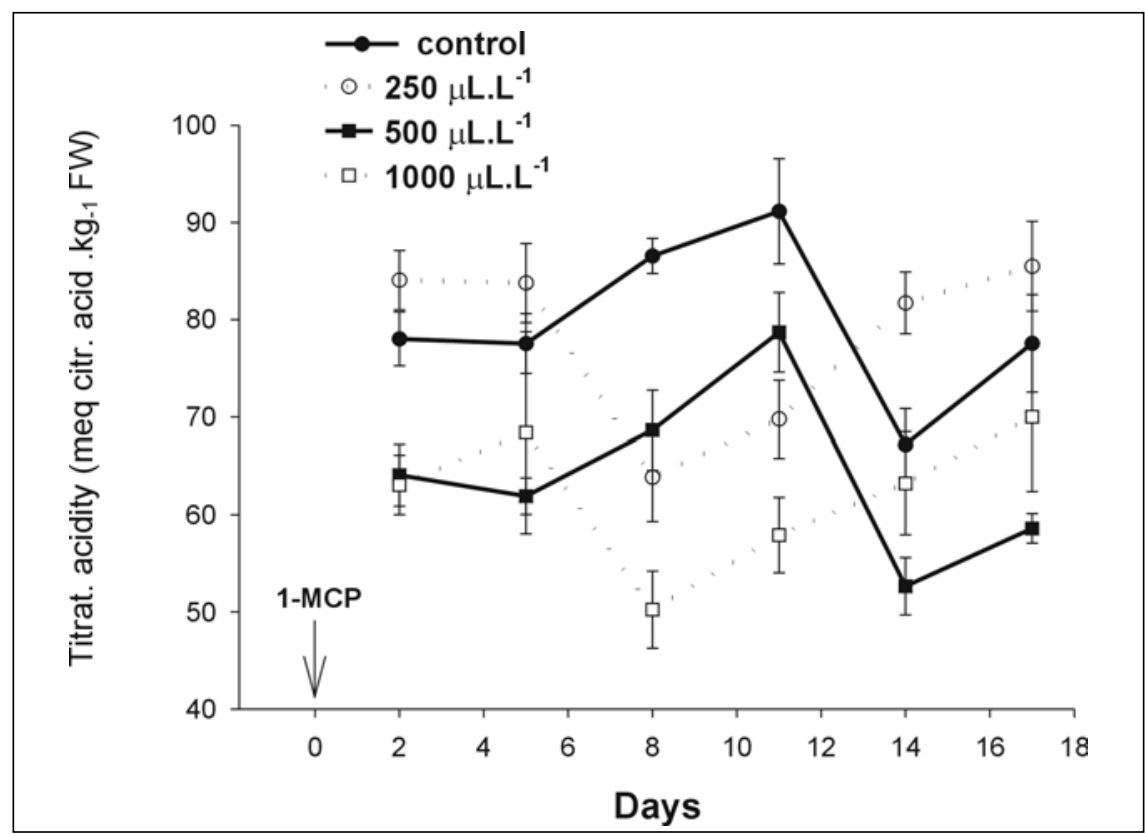

Figure 3. Titratable acidity (meq citric acid. $\mathrm{kg}^{-1}$ fresh weight) of tomato fruits treated with 1-MCP, stored for 2 days at ambient conditions $\left(23 \pm 1{ }^{\circ} \mathrm{C}\right.$; RH $\left.80-85 \%\right)$, with subsequent storage for 15 days at $20 \pm 1^{\circ} \mathrm{C}$ and $85-95 \%$ RH. Vertical bars indicate \pm SD.

The effects of 1-MCP on soluble solids content have been studied by different authors in different fruit crops. Fan et al. (1999) showed that soluble solids content were higher in 1-MCP treated "Delicious" and "Fuji" apples, but was not affected in "Ginger Gold", "Gala" and "Jonagold". Similarly, Porat et al. (1999) and Fan and Mattheis (2000) observed that citrus fruits and lettuce treated with 1-MCP had no significant changes in soluble solids content.

\section{Titratable acidity}

Titratable acidity was not affected by 1-MCP treatment. At the end of the storage period there were no significant differences among control and 1-MCP treated fruits (Figure 3). The results are 


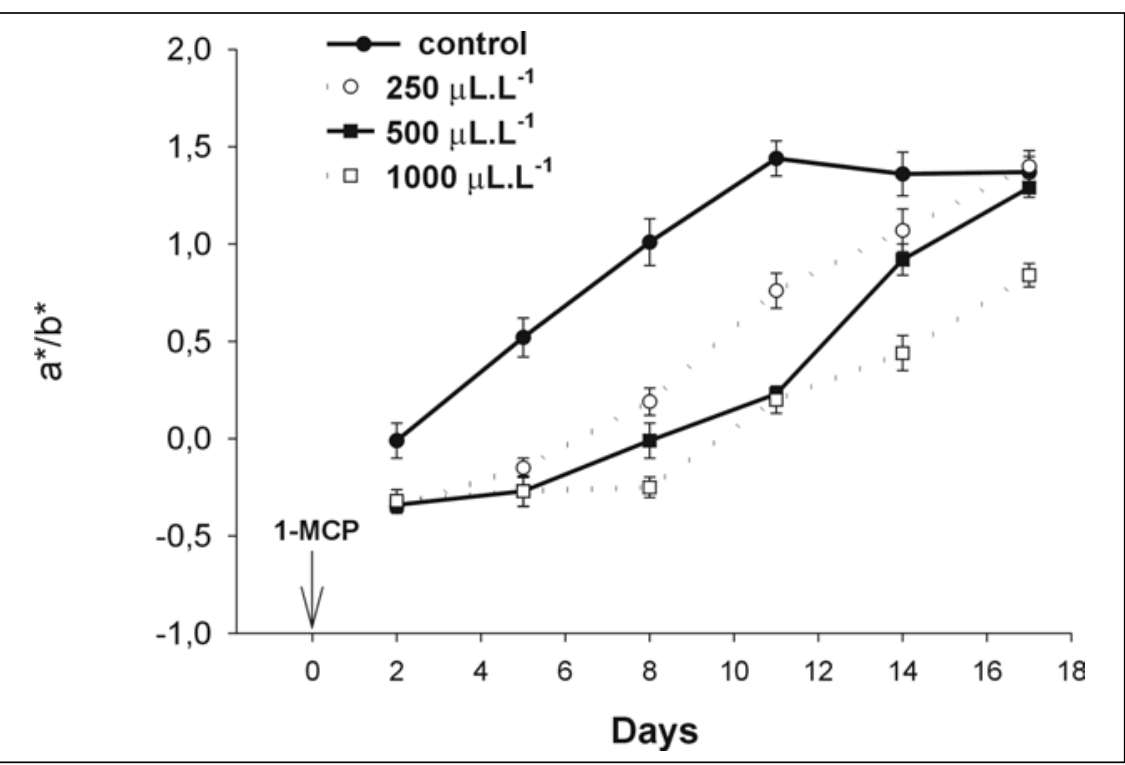

Figure 4. Color $\left(\mathrm{a}^{*} / \mathrm{b}^{*}\right.$ ratio) of tomato fruits treated with 1-MCP, stored for 2 days at ambient conditions $\left(23 \pm 1^{\circ} \mathrm{C}\right.$; RH $\left.80-85 \%\right)$, with subsequent storage for 15 days at $20 \pm 1^{\circ} \mathrm{C}$ and 85 $95 \% \mathrm{RH}$. Vertical bars indicate $\pm \mathrm{SD}$.

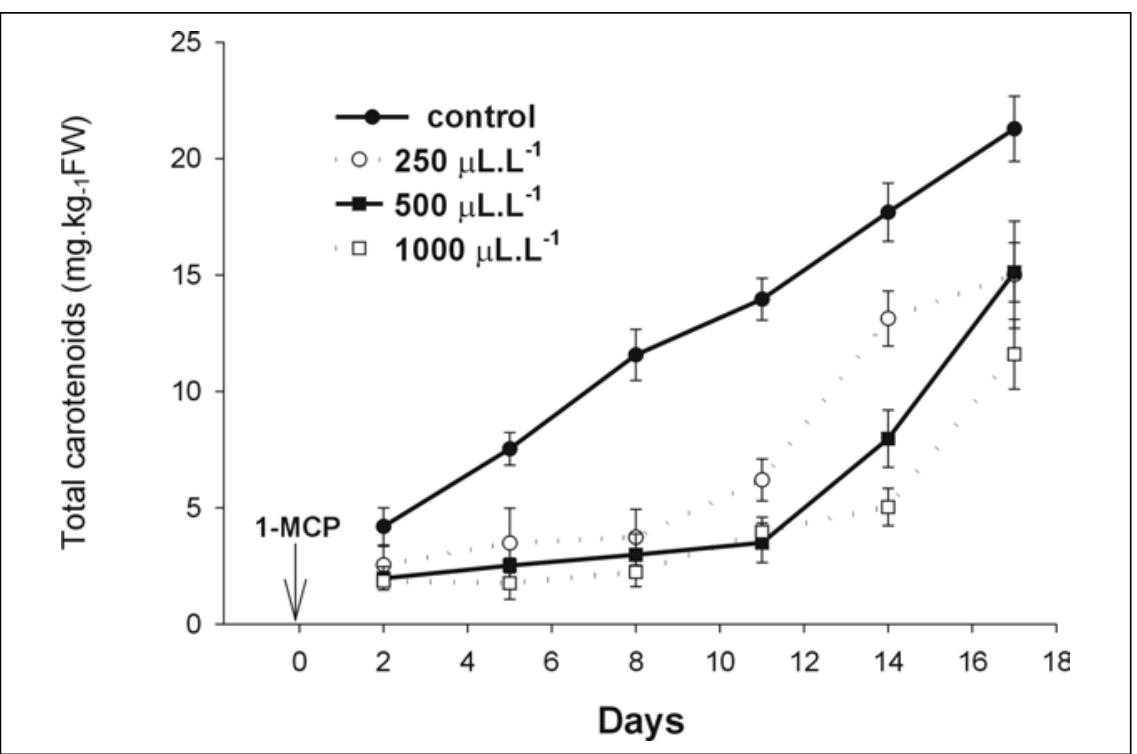

Figure 5. Total carotenoids (mg.kg-1 fresh weight) of tomato fruits treated with 1-MCP, stored for 2 days at ambient conditions $\left(23 \pm 1^{\circ} \mathrm{C}\right.$; RH $\left.80-85 \%\right)$, with subsequent storage for 15 days at $20 \pm 1^{\circ} \mathrm{C}$ and $85-95 \%$ RH. Vertical bars indicate \pm SD.

supported by Porat et al. (1999), who observed that citrus fruit treated with 1MCP showed no significant changes in organic acid content. On the other hand, Fan and Mattheis (2000) and Fan et al. (1999) showed that titratable acidity was significantly affected by 1-MCP treatments in lettuce and apples.

\section{Fruit color}

As 1-MCP concentrations increased, fruit color development was further delayed. After five days in storage, there was a significant difference in color development between control fruits and 1-MCP treated fruits (Figure 4). Tomato fruits treated with 250, 500 and 1000 mL. $\mathrm{L}^{-1}$ of 1-MCP showed degradation of chlorophyll and expression of carotenoids after 6 to 7,8 to 9 , and 10 to 11 days, respectively, of 1-MCP application.

External color development and firmness are among the most important quality characteristics of tomato fruits perceived by consumers as indicators of maturity. The application of 1-MCP retarded color development, thus extending the shelf life of tomato fruits. These results are similar to those of Jiang et al. (1999), who reported that banana color change was delayed when treated with 1-MCP. Similarly, Porat et al. (1999) observed that 1-MCP application delayed degreening of citrus fruits.

\section{Total carotenoids}

Trends observed for total carotenoids were similar to those for color (ratio $\left.\mathrm{a}^{*} / \mathrm{b}^{*}\right)$. As 1-MCP dose increased, pigment synthesis and expression was further delayed. At the end of the storage period, control fruits contained around $190 \%$ more total carotenoids than fruits treated with 1000 mL.L.-1 of 1-MCP (Figure 5).

Uneven degreening in individual fruits treated with 1-MCP was observed at the early stages of ripening. In some cases, color development started first at the stem end and then gradually shifted to the blossom end. Jiang et al. (1999) observed that bananas treated with 1MCP showed uneven skin degreening. They attributed this to positional differences in the rate of new synthesis of ethylene binding sites.

In conclusion, postharvest application of 1-MCP was an efficient method of delaying tomato fruit ripening. Fruits treated with 1-MCP had dramatically reduced the rate of fruits softening and color development in comparison with nontreated tomatoes. Titratable acidity and soluble solids were not significantly affected. As 1MCP concentrations increased, ripening was further delayed. Fruits treated with 250, 500, and $1000 \mathrm{~mL} . \mathrm{L}^{-1}$ of 1-MCP had ripening delays of 8 to 11,11 to 13 and 15 to 17 days, respectively. Thus, with the concentrations tested, 1-MCP allows growers to schedule tomato fruit ripening.

\section{ACKNOWLEDGEMENTS}

The authors are grateful to Conselho Nacional de Desenvolvimento Científico e Tecnológico (CNPq), and to Rohm \& Haas Ltda. 


\section{LITERATURE CITED}

ABELES, F.B.; MORGAN, P.W.; SALTVEIT JR. M.E. Ethylene in plant biology. San Diego, Academic Press, 1992. 414 p.

ABDI, N., MCGLASSON, W.B.; HOLFORD, P.; WILLIAMS, M.; MIZHARI, Y. Responses of climateric and supressed-climateric plums to treatment with propylene and 1methylcyclopropene. Postharvest Biology and Technology, v. 14, p. 29-39, 1998.

BLANKENSHIP, S.M.; SISLER, E.C. Response of apples to diazocyclopentadiene inhibition of ethylene binding. Postharvest Biology and Technology, v. 3, p. 95-101, 1993.

FAN, X.; BLANKENSHIP, S.M.; MATTHEIS, J.P. 1-methylcyclopropene inhibits apple ripening. Journal of the American Society for Horticultural Science, v. 124, p. 690-695, 1999.

FAN, X.; MATTHEIS, J.P. Reduction of ethyleneinduced physiological disorders of carrots and iceberg lettuce by 1-methylcyclopropene. HortScience, v. 35, p. 1312-1314, 2000.

GOLDING, J.B.; SHEARER, D.; WYLLIE, G.; MCGLASSON, W.B. Applications of 1methylcyclopropene and propylene to identify ethylene-dependent ripening process in mature banana fruit. Postharvest Biology and Technology, v. 14 , p. $87-98,1998$.
JIANG, Y.; JOYCE, D.C.; MACNISH, A.J. Extension of the shelf life of banana fruit by $1-$ methylyclopropene in combination with polyethylene bags. Postharvest Biology and Technology, v. 16, p. 187-193, 1999.

KU, V.V.V.; WILLS, R.B.H. Effect of $1-$ methylcyclopropene on the storage life of broccoli. Postharvest Biology and Technology, v. 17, p. 127 132, 1999.

KU, V.V.V.; WILLS, R.B.H.; BEN-YOSHUA, S $1-$ methylcyclopropene can differentially affect the postharvest life of strawberries exposed to ethylene. HortScience, v. 34, p. 637-639, 1999.

LELIÈVRE, J.M., LATCHÉ, A.; JONES, B.; BOUZAYEUN, M.; PECH, J.C. Ethylene and fruit ripening. Physiologia Plantarum, v. 101, p. 727 739, 1997.

LIME, B.J.; GRIFFITHS, F.P.; O’CONNOR, R.T.; HEINZELMANN, D.C.; MCCALL, E.R. Spectrophotometric methods for determining pigmentation - beta-carotene and lycopene - in ruby red grapefruit. Agric. Food Chem, v. 5, p. 941-944, 1957

MORETTI, C.L., SARGENT, S.A., HUBER, D.J., CALBO, A.G., PUSCHMANN, R. Chemical composition and physical properties of pericarp locule and placental tissues of tomatoes with internal bruising. Journal of the American Society for Horticultural Science, v. 123, p. 656-660, 1998.
PORAT, R., WEISS, B.; COHEN, L.; DAUS, A.; GOREN, R.; DROBT, S. Effects of ethylene and 1-methylcyclopropene on the postharvest qualities of 'Shamouti' oranges. Postharvest Biology and Technology, v. 15, p. 155-163, 1999.

SEREK, M., SISLER, E.C.; REID, M.S. Novel gaseous ethylene binding inhibitor prevents ethylene effects in potted flowering plants. Journal of the American Society for Horticultural Science, v. 119, p. 1230-1233, 1994.

SEREK, M., SISLER, E.C.; REID, M.S. Effects of 1-MCP on the vase life and ethylene response on cut flowers. Plant Growth Regulator, v. 16, p. 93-97, 1995.

SISLER, E.C. Ethylene binding components in plants. In: Matoo, A.K. and J.C. Suttle (ed.). The plant hormone ethylene. Boca Raton, CRC Press. p. 81-90. 1991.

SISLER, E.C., BLANKENSHIP, S.M.; GUEST, M. Competition of cycloctones and cycloctadienes for ethylene binding and activity in plants. Plant Growth Regulator v. 9, p. 157-164, 1990.

UMIEL, N.; GABELMAN, W.H. Analytical procedures for detecting carotenoids of carrot (Daucus carota L.) roots and tomato (Lycopersicon esculentum Mill.) fruits. Journal of the American Society for Horticultural Science, v. 96, p. 702-704, 1971.

USDA. U.S. Dept. Agric. United States standards for grades of fresh tomatoes. United States Department of Agriculture. Agricultural Marketing Service, Washington, D.C, 25 p, 1985. 